\title{
Use of babassu cake and pineapple byproduct silage in the diets of feedlot sheep
}

\section{Utilização da torta de babaçu e da silagem de resíduo de abacaxi em dietas para ovinos confinados}

\author{
Ernestina Ribeiro dos Santos Neta ${ }^{1 *}$; Daiany Íris Gomes ${ }^{1}$; Luis Rennan Sampaio \\ Oliveira ${ }^{1}$; Rafael Mezzomo'; Janaina Barros Luz²; Glenda Neves Bentes³; Williâne \\ Ferreira Oliveira ${ }^{3}$; Kaliandra Souza Alves ${ }^{1}$
}

\section{Highlights}

Babassu cake and pineapple byproduct silage can be used in sheep diets.

Babassu cake can replace soybean meal in sheep diets.

Replacement of soybean meal by babassu cake did not affect DM intake.

Use of pineapple byproduct silage improves the intake of nutrients in sheep.

\begin{abstract}
This study evaluated the use of babassu cake as a replacement for soybean meal and pineapple byproduct silage as roughage in the diets of feedlot sheep. Ten rumen-fistulated sheep were used and distributed in an experimental design consisting of two $5 \times 5$ Latin squares. Babassu cake replaced soybean meal at four concentration levels $(0,26.66,53.33$, and $80 \%)$, and pineapple byproduct silage was used as roughage. A treatment was also evaluated in which elephant grass silage was used as roughage and corn and soybean meal were used as the concentrate. No effect of babassu cake as a replacement for soybean meal on dry matter intake, neutral detergent fiber, or crude protein was observed. Higher babassu cake replacement levels in the diets resulted in linear reductions in the digestibility of the dry matter, neutral detergent fiber, organic matter, nonfiber carbohydrates and total carbohydrates. For the digestibility of the crude protein, no effect was observed after the addition of babassu cake. The replacement levels of the babassu cake had no effect on the intake and retention of the daily nitrogen, ammonia nitrogen and ruminal $\mathrm{pH}$. Babassu cake could replace soybean meal at concentrations of up to $80 \%$ when the roughage source was pineapple byproduct silage. Compared with elephant grass silage, pineapple byproduct silage improves nutrient intake and digestibility and nitrogen intake, retention, and absorption without compromising the ruminal $\mathrm{pH}$ or ammonia nitrogen of feedlot sheep.
\end{abstract}

Key words: Digestibility. Intake. Ruminal parameters. Small ruminants.

1 Profs. D.Sc., Department of Animal Science, Amazonia Rural Federal University, UFRA, Parauapebas, PA, Brazil. E-mail: tina.neta@yahoo.com.br; daiany.i.gomes@gmail.com; rennanvet@yahoo.com.br; mezzomo@zootecnista.com.br; kaliandra.souza.alves@gmail.com.

2 Researcher D.Sc., Prefeitura Municipal de Parauapebas, PMP, Parauapebas, PA, Brazil. E-mail: janaina.ufra@hotmail.com

${ }_{3}$ Zootechnist, Amazonia Rural Federal University, UFRA, Parauapebas, PA, Brazil. E-mail: gnevesbentes@gmail.com; williane-01@hotmail.com

* Author for correspondence

Received: Mar. 06, 2020 - Approved: Nov. 30, 2020 


\section{Resumo}

Neste experimento avaliou-se o uso de torta de babaçu em substituição ao farelo de soja e silagem de coprodutos de abacaxi como volumoso em dietas de ovinos confinados. Dez ovinos fistulados no rúmen foram utilizados e distribuídos em delineamento experimental constituído por dois quadrados latinos $5 \times 5$. A torta de babaçu substituiu o farelo de soja em quatro níveis de concentração $(0 ; 26,66 ; 53,33$ e $80 \%)$, e a silagem de subprodutos de abacaxi foi utilizada como volumoso. Também foi avaliado um tratamento em que a silagem de capim elefante foi utilizada como volumoso e o milho e o farelo de soja foram utilizados como concentrado. Não houve efeito $(P>0,05)$ da substituição do farelo de soja pela torta de babaçu sobre os consumos de matéria seca, fibra em detergente neutro e proteína bruta. Maiores níveis de substituição do farelo de soja pela torta de babaçu nas dietas resultaram em reduções lineares na digestibilidade da matéria seca, fibra em detergente neutro, matéria orgânica, carboidratos não fibrosos e carboidratos totais. Para a digestibilidade da proteína bruta, nenhum efeito foi observado. Os níveis de substituição de torta de babaçu também não influenciaram a ingestão e retenção de nitrogênio, nitrogênio amoniacal e pH ruminal. A torta de babaçu pode substituir o farelo de soja em até $80 \%$ quando a fonte de volumoso for a silagem do coproduto de abacaxi. A silagem de coproduto de abacaxi em comparação à silagem de capim elefante melhora o consumo e digestibilidade de nutrientes, ingestão, retenção e absorção de nitrogênio, sem comprometer os parâmetros ruminais de ovinos confinados.

Palavras-chave: Consumo. Digestibilidade. Parâmetros ruminais. Pequenos ruminantes.

\section{Introduction}

Soybean meal is the protein concentrate most commonly used in sheep diet supplementation in Brazil. However, it increases production costs because of demand competition with other animal species and due to price fluctuations throughout the year. Therefore, the use of raw materials from regional plants to partially replace soybean meal in the diets of sheep offers an alternative that maximizes the productive potential and minimizes the costs of feed production.

The Amazonian flora includes the babassu palm tree (Orbignya sp.). Its fruits are used for the manufacture of oil, soap, and cosmetics as well as other domestic products. Babassu cake, which contains approximately 21 to 25\% crude protein (Santos et al., 2017; Sá et al., 2015), is a byproduct of babassu palm oil extraction and can be used in ruminant feed. Brazil is third in the global production of pineapple (Ananas comosus), with 2.478 million tons produced every year (United Nations Conference on Trade and Development [UNCTD], 2016). The largest production is concentrated in the state of Pará, with approximately 320 million fruits per year Instituto Brasileiro de Geografia e Estatística [IBGE], (2013). The byproducts of pineapple juice production include bagasse, peel, and crown, which represent $45 \%$ of the fruit.

In ruminant diets, byproducts must be combined with other foodstuffs to establish a carefully balanced nutritional content that allows efficient fermentation in the rumen. Therefore, the evaluation of byproducts must include, in addition to their chemical composition, nutrient intake, and digestibility, the possibility of changes in ruminal parameters, because these factors all contribute to the level of animal performance.

This study aimed to evaluate the use of babassu cake as a replacement for soybean 
meal in the diets of sheep fed pineapple byproduct silage (PBS), as well as the use of PBS as a roughage replacement for elephant grass silage (EGS), focusing on the nutrient intake and digestibility, nitrogen balance, and ruminal parameters of sheep.

\section{Material and Methods}

\section{Animal care}

The protocol used in this study follows the ethical principles of animal experimentation of the National Council for the Control of Animal Experimentation (NCCAE) and was approved by the Ethics Committee for Animal Use of the Federal Rural University of Amazonia, Brazil (ECAU-UFRA; protocol: 003/2014).

\section{Experimental rations}

Ten crossbred Santa Inês castrated male sheep with an average weight of $43.77 \pm 2.82 \mathrm{~kg}$ were used. These sheep, which were fistulated in the rumen, were individually housed in $1.0 \times 2.0 \mathrm{~m}$ metabolic cages with feeding and drinking troughs.

The experimental design used was composed of two simultaneous $5 \times 5$ Latin squares (periods $x$ treatments). Each experimental period had a duration of 14 days, with the animals adapting to the diets for the first 7 days and collections being conducted in the remaining 7 days (Detmann et al., 2001; Lazzarini et al., 2013). The replacement of soybean meal by babassu cake was evaluated at four different concentrations $(0,26.66$, 53.33, and 80\%), using PBS composed of peel, crown, and bagasse as roughage. An additional treatment, in which EGS (Pennisetum purpureum Schum) was the roughage and corn and soybean meal were used as the concentrate (Tables 1 and 2), was evaluated. For a total of five experimental treatments, all the diets contained a roughage:concentrate ratio of $40: 60$. The rations were formulated to meet a weight gain requirement of $200 \mathrm{~g}$ animal day $^{-1}$ National Research Council [NRC], 2007).

\section{Table 1}

\section{Chemical composition of the main ingredients of the experimental diets}

\begin{tabular}{lccccc}
$\begin{array}{l}\text { Chemical composition, } \\
\mathrm{g} \mathrm{kg}^{-1} \text { of DM }\end{array}$ & $\begin{array}{c}\text { Elephant } \\
\text { grass silage }\end{array}$ & $\begin{array}{c}\text { Pineapple } \\
\text { coproducts silage }\end{array}$ & $\begin{array}{c}\text { Soybean } \\
\text { meal }\end{array}$ & $\begin{array}{c}\text { Babassu } \\
\text { cake }\end{array}$ & Corn \\
\hline Dry matter, kg $^{-1}$ of NM & 208.1 & 156.2 & 868.4 & 868.7 & 892.0 \\
\hline Organic matter & 910.9 & 928.9 & 929.2 & 953.1 & 986.1 \\
\hline Mineral matter & 89.1 & 71.1 & 70.8 & 46.9 & 13.9 \\
\hline Crude protein & 45.5 & 95.6 & 520.8 & 198.2 & 76.6 \\
\hline Ether extract & 20.8 & 32.1 & 11.3 & 68.1 & 48.7 \\
\hline NDF $^{\text {a }}$ & 735.6 & 519.0 & 146.3 & 626.7 & 140.8 \\
\hline Acid neutral detergent & 459.2 & 364.8 & 99.8 & 337.4 & 61.2 \\
\hline Lignin & 64.2 & 47.2 & 8.6 & 94.8 & 10.5 \\
\hline NFC $^{b}$ & 109.0 & 282.2 & 250.8 & 60.1 & 720.0 \\
\hline iNDF $^{\mathrm{c}}$ & 351.1 & 262.0 & 14.1 & 299.8 & 17.1
\end{tabular}

${ }^{a}$ Neutral detergent fiber corrected for ash and protein; ${ }^{b}$ Nonfiber carbohydrates; ${ }^{\mathrm{c}}$ Indigestible neutral detergent fiber 


\section{Table 2}

\section{Proportion of ingredients and chemical composition of the diets}

\begin{tabular}{|c|c|c|c|c|c|}
\hline \multirow[t]{2}{*}{ Item } & \multicolumn{4}{|c|}{$\begin{array}{c}\text { Replacement of soybean meal by babassu cake } \\
\text { (\% Dry Matter) }\end{array}$} & \multirow[t]{2}{*}{ EGSa } \\
\hline & 0 & 26.66 & 53.33 & 80 & \\
\hline \multicolumn{6}{|c|}{ Proportion of ingredients ( $\mathrm{kg}^{-1}$ of DM) } \\
\hline Elephant grass silage & - & - & - & - & 400.0 \\
\hline Pineapple coproducts silage & 400.0 & 400.0 & 400.0 & 400.0 & - \\
\hline Babassu cake & - & 66.7 & 133.3 & 200.0 & - \\
\hline Soybean meal & 250.0 & 183.3 & 116.7 & 50.0 & 250.0 \\
\hline Corn & 330.0 & 323.0 & 317.0 & 308.5 & 331.5 \\
\hline Urea & - & 7.0 & 13.5 & 20.5 & 3.5 \\
\hline Mineral mixture & 8.0 & 8.0 & 8.0 & 8.0 & 8.0 \\
\hline Dicalcium phosphate & 5.0 & 3.0 & 0.5 & 0.0 & 3.5 \\
\hline Limestone calcitic & 7.0 & 9.0 & 11.0 & 13.0 & 3.5 \\
\hline \multicolumn{6}{|c|}{ Chemical composition ( $\mathrm{kg}^{-1}$ of DM) } \\
\hline Dry matter, $\mathrm{g} \mathrm{kg}^{-1}$ of $\mathrm{NM}$ & 593.5 & 594.3 & 599.3 & 595.9 & 614.2 \\
\hline Organic matter & 930.8 & 932.7 & 935.0 & 935.5 & 928.2 \\
\hline Mineral matter & 64.2 & 64.3 & 64.5 & 64.5 & 68.3 \\
\hline Crude protein & 193.7 & 191.2 & 187.4 & 184.7 & 183.6 \\
\hline Ether extract & 31.7 & 35.2 & 38.7 & 42.0 & 27.3 \\
\hline NDF & 290.6 & 321.7 & 352.8 & 383.7 & 377.5 \\
\hline Acid detergent fiber & 191.1 & 206.5 & 222.0 & 237.3 & 228.9 \\
\hline Lignin & 24.5 & 30.2 & 35.8 & 41.5 & 31.3 \\
\hline NFC & 419.7 & 400.1 & 380.8 & 361.7 & 349.6 \\
\hline iNDF & 118.3 & 137.2 & 156.1 & 175.0 & 149.6 \\
\hline
\end{tabular}

aEGS: Treatment in which the elephant grass silage was used as roughage. NM: Natural matter; NDF: Neutral detergent fiber; NFC: Nonfiber carbohydrates; iNDF: Indigestible neutral detergent fiber.

Guaranteed levels (per kg of mineral mixture) Cobalt 30mg; Copper 350 mg; Chrome 11.70 mg; Sulfur 11.70 g; 700 mg iron; Fluorine 600 mg; phosphorus 60 g; iodine 50 mg; Manganese 1200 mg; Molybdenum 180 mg; Selenium 15 mg; Sodium 132 g; Zinc $2600 \mathrm{mg}$.

To obtain silage from pineapple byproducts, which consisted of peel, crown, and bagasse, a stationary chopper without a sieve was used to grind the different components separately (peel and crown). The ground components were then ensiled by alternating layers of peel, bagasse, and crown in 200-liter polyethylene tanks. The silage material was compacted by stomping, after which the silos were sealed and closed.

The elephant grass ( $P$. purpureum Schum. cv. Cameroon Roxo) silage was obtained from a well-established grass crop area in the small ruminant sector. The area contains a small slope, and at each harvest, it was fertilized with $80 \mathrm{~kg}$ of nitrogen and $30 \mathrm{~kg}$ 
of potassium chloride per hectare. The grass was mechanically harvested at approximately $1.80 \mathrm{~m}$ in height and 100 days of regrowth and was then chopped into $1.5-\mathrm{cm}$ particles using an ensiling machine attached to a tractor; the materialwasthencompactedinanaboveground silo after each unloading. Immediately after the harvesting and compaction of the material, the silo was sealed with double-sided canvas and opened for use after 100 days of ensiling, at which time the contents presented the smell and color characteristics of good silage. No additives were used in any of the silages.

\section{Experimental procedures and laboratory analysis}

The rations were two daily meals provided at 08:00 and 16:00, and the volume was adjusted to obtain 10\% leftovers from the amount supplied. For intake calculation, the amount of feed provided as well as the leftovers were recorded from day 8 to day 12 of each experimental period. For digestibility quantification, all the feces were collected during the same period in which intake was measured. The feces were collected every 8 hours and weighed. Then, at the end of each day, they were homogenized. Following homogenization, a subsample was weighed and predried in a forced-air oven at $55^{\circ} \mathrm{C}$ for 72 hours.

Samples of the pineapple byproduct silage and elephant grass silage, concentrate ingredients, leftovers, and feces (processed at $1 \mathrm{~mm}$ ) were analyzed for dry matter (DM), crude protein (CP), ether extract (EE), neutral detergent fiber (corrected for ash and protein) (NDF) and acid detergent fiber (ADF) (Detmann, Souza, \& Valadares, 2012). The intake and apparent digestibility of the DM and nutrients were subsequently determined.

The samples of the ingredients and the leftovers, ground to $2 \mathrm{~mm}$, were used to quantify the indigestible neutral detergent fiber (iNDF) intake according to Valente et al. (2011).

The nonfiber carbohydrate (NFC) content was calculated according to the equation proposed by Detmann and Valadares (2010):

$\mathrm{NFC}=100-\mathrm{MM}-\mathrm{EE}-\mathrm{NDF}-(\% \mathrm{CP}-$ $\% \mathrm{CP}$ derived from urea $+\%$ urea), where $\mathrm{MM}$, $\mathrm{EE}, \mathrm{NDF}$, and $\mathrm{CP}$ correspond to the mineral matter, ether extract, neutral detergent fiber (free of ash and protein), and crude protein, respectively. The energy intake of the animals as calculated is the product between the dry matter intake and energy density of the diets, using the formula recommended by the NRC (2000):

TDN (\%) $=\mathrm{DCP}+2.25 \times \mathrm{DEE}+\mathrm{DNFC}$ + DNDF, where DCP, DEE, DNFC, and DNDF correspond to the digestible crude protein, digestible ether extract, digestible nonfiber carbohydrates, and digestible neutral detergent fiber (free of ash and protein), respectively, calculated from the digestibility coefficients. The digestible energy (DE) was obtained from the TDN by multiplying it by 4.409 , and the DE value was then multiplied by a factor of 0.82 to estimate the metabolizable energy (ME) intake.

In each experimental period, urine samples were obtained from the collection of all urine from the animals in metabolic cages via holes that directed the urine to containers with screened funnels. One hundred milliliters of a $20 \%$ sulfuric acid solution was added to 
each container daily. The urine samples were collected for 5 days (on the same days as fecal collection (days 8 to 12)) and always at the same time. At the end of each day, the total volume of the excreted urine was determined, the urine was homogenized, and a subsample was collected to determine the levels of total $\mathrm{N}$ (Detmann et al., 2012) and urine urea $N$ (UUN) using the modified diacetyl method (commercial kits). The concentration of UUN in the urine was determined by multiplying the urea concentration in the urine by 0.466 , which corresponded to the $\mathrm{N}$ content in the urea.

The nitrogen balance (NB) was determined according to Decandia, Sitzia, Cabiddu, Kababya and Molle (2000) by measuring the mean amount of nitrogen ingested during the 5 days when the intake of the animal was being measured and then subtracting from this value the amount excreted by the animals, expressed in $\mathrm{g}_{\text {animal }}{ }^{-1}$ day $^{-1}$.

On day 13 of each experimental period, blood was collected 4 hours after feeding and then immediately centrifuged at $2700 \mathrm{rpm}$ for 20 minutes to obtain blood serum, which was stored at $-20^{\circ} \mathrm{C}$ for subsequent analysis of the serum urea nitrogen (SUN) concentration. For the SUN analyses, the samples were thawed at room temperature and evaluated using the same method previously described for urine.

To assess the $\mathrm{pH}$ of the ruminal fluid and to determine the ruminal ammonia nitrogen concentration $\left(\mathrm{N}-\mathrm{NH}_{3}\right)$, ruminal fluid was collected on day 14 of each experimental period at $0,6,12$, and 18 hours after the first feeding. After obtaining $\mathrm{pH}$ readings, $50-\mathrm{mL}$ aliquots of ruminal fluid were filtered, added to a container containing $1 \mathrm{~mL}$ of $\mathrm{H}_{2} \mathrm{SO}_{4}(1: 1)$, and frozen at $-20{ }^{\circ} \mathrm{C}$ for later analysis of the ruminal ammonia nitrogen concentrations by colorimetry (Detmann et al., 2012).

\section{Statistical analyses}

Variance and regression analyses were carried out, adopting 0.05 as the critical level of the probability of a type I error. Comparisons between treatments were performed as follows: linear and quadratic effects were used for the replacement levels of soybean meal with babassu cake $(0,26.66,53.33$, and $80 \%$ replacement) and a "roughage" effect (PBS and $0 \%$ babassu cake versus treatment with EGS as roughage and 0\% babassu cake). All the statistical procedures were conducted in Statistical Analysis Software [SAS] (2012). The statistical model adapted was:

$$
Y i j k=\mu+A i+P j+T k+\varepsilon i j k
$$

where Yijk is the variable measured, $\mu$ is a general constant, $\mathrm{A} i$ is the random effect of animal $\mathrm{i}, \mathrm{Pj}$ is the random effect of period $\mathrm{j}$, Tk is the effect of treatment k, and عijk is the experimental error.

\section{Results and Discussion}

The dry matter (DM), neutral detergent fiber (NDF), organic matter (OM), crude protein $(C P)$, ether extract (EE), total carbohydrates (TC), total digestible nutrients (TDN), and metabolizable energy intake (MEI) were not affected $(P>0.05)$ by adding babassu cake to the diets. However, the indigestible neutral detergent fiber (iNDF) intake increased linearly $(\mathrm{P}<0.05)$ with the addition of babassu cake. The nonfiber carbohydrate (NFC) intake decreased linearly $(P<0.05)$ with the increasing inclusion of babassu cake (Table 3 ).

A difference $(P<0.05)$ was observed between the roughage sources (PBS and EGS), where the animals fed PBS consumed greater amounts of nutrients (DM, CP, EE, OM, NFC, TC, and TDN) than the animals fed EGS. 


\section{Table 3}

Intake of dry matter and nutrients as a function of the replacement levels of soybean meal by babassu cake in sheep diets containing pineapple coproducts silage or elephant grass silage as roughage

\begin{tabular}{|c|c|c|c|c|c|c|c|c|c|}
\hline \multirow{2}{*}{ Item } & \multicolumn{4}{|c|}{$\begin{array}{c}\text { Replacement of soybean meal by } \\
\text { babassu cake (\% DM) }\end{array}$} & \multirow{2}{*}{ EGS } & \multirow{2}{*}{ SEM } & \multicolumn{3}{|c|}{$p$-value ${ }^{a}$} \\
\hline & 0 & 26.66 & 53.33 & 80 & & & L & $Q$ & Roughage \\
\hline \multicolumn{10}{|c|}{ Nutrients intake $\left(\mathrm{kg}\right.$ day $\left.^{-1}\right)$} \\
\hline Dry matter & 1.38 & 1.32 & 1.29 & 1.25 & 1.03 & 0.084 & 0.300 & 0.814 & 0.005 \\
\hline Organic matter & 1.29 & 1.23 & 1.20 & 1.17 & 0.96 & 0.078 & 0.324 & 0.828 & 0.005 \\
\hline NDF & 0.39 & 0.42 & 0.45 & 0.47 & 0.37 & 0.029 & 0.051 & 0.921 & 0.688 \\
\hline Crude protein & 0.27 & 0.25 & 0.24 & 0.23 & 0.19 & 0.016 & 0.082 & 0.705 & 0.003 \\
\hline Ether extract & 0.04 & 0.05 & 0.05 & 0.05 & 0.03 & 0.002 & 0.055 & 0.969 & 0.000 \\
\hline NFC ${ }^{b}$ & 0.63 & 0.56 & 0.52 & 0.48 & 0.38 & 0.030 & 0.002 & 0.697 & $<0.001$ \\
\hline $\mathrm{iNDF}^{\mathrm{c}}$ & 0.16 & 0.18 & 0.20 & 0.20 & 0.15 & 0.012 & 0.007 & 0.700 & 0.484 \\
\hline TC & 0.98 & 0.94 & 0.92 & 0.89 & 0.74 & 0.059 & 0.319 & 0.838 & 0.006 \\
\hline TDN & 1.06 & 1.02 & 0.95 & 0.93 & 0.76 & 0.064 & 0.113 & 0.838 & 0.002 \\
\hline MEI (MJ day ${ }^{-1}$ ) & 16.09 & 15.38 & 14.37 & 14.08 & 11.49 & 0.285 & 0.113 & 0.838 & 0.002 \\
\hline
\end{tabular}

a Contrasts Linear (L) and quadratic (Q); Roughage: Effect of the contrast between the treatment with $0 \%$ babassu cake with pineapple coproducts silage and the diet containing elephant grass silage as roughage. EGS: Elephant grass silage as roughage and corn and soybean meal-based concentrate; SEM: standard error of the mean; NDF: Neutral detergent fiber; NFC: Nonfiber carbohydrates; iNDF: Indigestible neutral detergent fiber; TC: Total carbohydrates; TDN: Total digestible nutrients; MEl: Metabolizable energy intake.

${ }^{\mathrm{b}} \mathrm{Y}=0.6178-0.0017 x ;{ }^{c} Y=0.165+0.0005 x$.

The increase in the intake of iNDF with the inclusion of babassu cake likely occurred due to the increase in iNDF in the diets with higher inclusion levels because babassu cake has greater levels (299.8 $\mathrm{g} \mathrm{kg}^{-1} \mathrm{DM}$ ) than soybean meal (14.1 $\left.\mathrm{g} \mathrm{kg}^{-1}\right)$, therefore increasing its proportion in the experimental diets containing babassu cake.

Although there was no influence on NDF intake, the increases in the levels of iNDF and the higher concentration of NDF in babassu cake in relation to that in soybean meal could generate a filling effect. However, this factor was not enough to cause physical limitations and reduce the DM intake for the diets supplemented with babassu cake, possibly due to the physical characteristics of the babassu cake (i.e., the small size of its particles). This resulted in the low effectiveness of the fiber in the rumen; it is likely that the potentially degradable fractions were quickly digested by the sheep after ingestion, thus preventing a filling effect (Izumi, Tamura, Fujii, Nakatsuji, \& Morita, 2018). The characteristics of the babassu cake made the degradation process more efficient by ensuring sufficient contact surfaces for the colonization of microorganisms and reducing the retention capacity of these particles in the rumen (Kammers \& Allen, 2011; Gomes et al., 2012). In addition, even the highest levels of NDF in the diets (383.7 $\mathrm{g} \mathrm{kg}^{-1} \mathrm{DM}$; Table 2), which 
corresponded to $80 \%$ babassu cake, were not sufficient to promote an effect on their intake and remained below the NDF values (550 to $600 \mathrm{~g} \mathrm{~kg}^{-1} \mathrm{DM}$ ) that were negatively correlated with DM intake (Van Soest, 1965).

According to Allen (1996), as the potentially digestible NDF content decreases in the rumen due to degradation, the proportion of iNDF increases. The release of these fractions increases the density of the indigestible neutral detergent fiber, transporting it to the most ventral portion of the rumen near the escape zone. Thus, the quicker the degradation of ruminal NDF, the faster the release of indigestible neutral detergent fiber, increasing the space available for the animal to consume more food. In this context, it is believed that although there was a reduction in the digestibility of the NDF, this alteration did not reduce the passage rate and thus did not affect DM intake, even for the animals fed greater proportions of babassu cake.

Higher cake babassu inclusion levels in the diets resulted in linear reductions $(P<0.05)$ in the digestibility of DM, NDF, OM, NFC and TC. For the digestibility of the $C P$, no effect $(P>0.05)$ was observed after the addition of babassu cake (Table 4). An effect was observed for the roughage source on the digestibility of $\mathrm{TC}$, TDN (in percentage) and $\mathrm{ME}\left(\mathrm{MJ} \mathrm{kg}^{-1}\right)(\mathrm{P}<0.05)$, where the animals fed the diet containing EGS experienced lower values.

Another relevant aspect of using babassu cake is the amount of energy provided by the experimental diets, which is confirmed by the lack of variation in the TDN levels. This hypothesis is partially explained by the increase in the digestibility of $E \mathrm{E}$, which, because of its high energy density $\left(9.4 \mathrm{kcal} \mathrm{g}^{-1}\right)$, contributed to the lack of an effect on the TDN, despite the decrease in the digestibility of the DM, TDN, and NFC intake.

The reduction in the digestibility of the DM and TC observed with the addition of babassu cake probably occurred due to a reduction in the intake of TDN and an increase in the intake of iNDF. This can be explained by the reduction in the NFC content with the increased inclusion of babassu cake in the diets. This led to a greater concentration of structural carbohydrates in the diets and, therefore, a greater intake of these carbohydrates than of the easily fermentable carbohydrates found in soybean meal, thus promoting a reduction in the digestibility of DM, OM, NFC and TC. 


\section{Table 4}

Coefficient of digestibility of dry matter and nutrients as a function of the replacement levels of soybean meal by babassu cake in sheep diets containing pineapple coproducts silage or elephant grass silage as roughage

\begin{tabular}{|c|c|c|c|c|c|c|c|c|c|}
\hline \multirow{2}{*}{ Item (\%) } & \multicolumn{4}{|c|}{$\begin{array}{c}\text { Replacement of soybean meal by } \\
\text { babassu cake (\% DM) }\end{array}$} & \multirow{2}{*}{ EGS } & \multirow{2}{*}{ SEM } & \multicolumn{3}{|c|}{$p$-value ${ }^{a}$} \\
\hline & 0 & 26.66 & 53.33 & 80 & & & L & $Q$ & Roughage \\
\hline Dry matter ${ }^{b}$ & 0.76 & 0.77 & 0.73 & 0.73 & 0.75 & 0.918 & $<0.0001$ & 0.613 & 0.090 \\
\hline Organic matter ${ }^{c}$ & 0.78 & 0.78 & 0.75 & 0.74 & 0.77 & 0.862 & $<0.0001$ & 0.646 & 0.072 \\
\hline $\mathrm{NDF}^{\mathrm{d}}$ & 0.63 & 0.64 & 0.61 & 0.61 & 0.64 & 1.667 & 0.040 & 0.623 & 0.871 \\
\hline Crude protein & 0.78 & 0.80 & 0.77 & 0.78 & 0.79 & 0.959 & 0.507 & 0.959 & 0.554 \\
\hline Ether extract & 0.82 & 0.86 & 0.87 & 0.90 & 0.82 & 0.943 & $<0.0001$ & 0.729 & 0.778 \\
\hline NFC ${ }^{f}$ & 0.89 & 0.90 & 0.87 & 0.87 & 0.88 & 0.674 & 0.006 & 0.329 & 0.515 \\
\hline $\mathrm{TC}^{\mathrm{g}}$ & 0.78 & 0.78 & 0.73 & 0.73 & 0.76 & 0.924 & $<0.0001$ & 0.594 & 0.020 \\
\hline $\mathrm{TDN}^{\mathrm{h}}$ & 0.77 & 0.77 & 0.74 & 0.74 & 0.74 & 0.852 & 0.002 & 0.609 & 0.025 \\
\hline ME (MJ kg-1) & 11.62 & 11.70 & 11.20 & 11.24 & 11.24 & 0.037 & 0.002 & 0.609 & 0.025 \\
\hline
\end{tabular}

${ }^{a}$ Contrasts Linear $(\mathrm{L})$ and quadratic $(\mathrm{Q})$; Roughage: Effect of the contrast between the treatment with $0 \%$ babassu cake with pineapple coproducts silage and the diet containing elephant grass silage as roughage. EGS: Elephant grass silage as roughage and corn and soybean meal-based concentrate; SEM: Standard error of the mean; NDF: Neutral detergent fiber; NFC: Nonfiber carbohydrates; TC: Total carbohydrates; TDN: Total digestible nutrients; ME: Metabolizable energy.

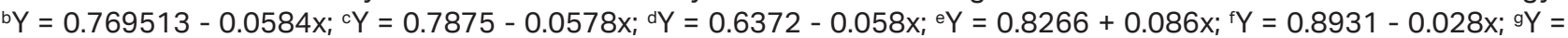
$0.7868-0.080 x ;{ }^{h} Y=0.7725-0.0403 x ;{ }^{i} Y=11.62-0.0014 x$.

The lack of effects on the CP intake with soybean meal replacement probably occurred due to the maintenance of the isoproteic diets. Furthermore, the nutritional value of the babassu cake is demonstrated by the lack of effects on the coefficient of digestibility of this nutrient, with all diets reaching levels above 0.75. This was possible due to the use of urea, and for this reason, the nitrogen demands were probably achieved even with the partial replacement of soybean meal for babassu cake.

Regarding the roughage source, the animals fed the PBS had higher DM intake $(P<0.05)$ than the animals fed the EGS. This can be explained by the increased concentration of NFC, which improved the passage of digesta in the gastrointestinal tract (Lins et al., 2016), and decreased NDF contents in diets with PBS, because the NDF content in the feed correlates with DM intake. This occurs because the fermentation and the rate of passage of the fiber fraction through the rumen reticulum are slower than those of other dietary constituents and have a large effect on rumen filling and retention time (Ranathunga, Kalscheur, \& Herrick, 2019). Furthermore, the higher level of iNDF and the greater lignification of the diets containing EGS influenced the DM intake Detmann, Gionbelli and Huhtanen (2014b) and the lower TC digestibility, providing a reduction in the energy availability in the diets containing EGS.

Due to the higher DM intake in the diet containing PBS, a higher intake was observed for $\mathrm{CP}, \mathrm{EE}, \mathrm{OM}$, and NFC in this diet. In addition, 
the largest digestibility values of TC and the percentage of total digestible nutrients were observed for the diet containing PBS as roughage, which may be indicative of improvement in ruminal digestion conditions (Conceição et al., 2016). Thus, it can be inferred that the smaller values observed for the intake, retention, and absorption of nitrogen for the diets containing EGS occurred because of the lower intake of DM and CP in these diets.
The replacement of soybean meal by babassu cake did not affect $(P>0.05)$ the intake or the balance of $\mathrm{N}$ and urea $\mathrm{N}$ in the plasma and urine. An effect was observed for the roughage source $(P<0.05)$ on the consumed $N$, retained/ ingested $\mathrm{N}$, and retained/absorbed $\mathrm{N}$, with the animals fed EGS having the smallest values for all parameters, despite there being no effect $(P>0.05)$ on the urea $\mathrm{N}$ in the plasma and urine. The levels of $\mathrm{N}-\mathrm{NH}_{3}$ and the ruminal $\mathrm{pH}$ were not affected by the treatments ( $P>0.05$; Table 5).

\section{Table 5}

Balance of nitrogen compounds and ruminal parameters as a function of the replacement levels of soybean meal by babassu cake in sheep diets containing pineapple coproducts silage or elephant grass silage as roughage

\begin{tabular}{|c|c|c|c|c|c|c|c|c|c|}
\hline \multirow{2}{*}{ Item } & \multicolumn{4}{|c|}{$\begin{array}{c}\text { Replacement of soybean meal } \\
\text { by babassu cake (\% DM) }\end{array}$} & \multirow{2}{*}{ EGS } & \multirow{2}{*}{ SEM } & \multicolumn{3}{|c|}{$p$-value ${ }^{a}$} \\
\hline & 0 & 26.66 & 53.33 & 80 & & & $L$ & $\bar{Q}$ & Roughage \\
\hline \multicolumn{10}{|c|}{ Nutrients intake $\left(\mathrm{kg}\right.$ day $\left.^{-1}\right)$} \\
\hline Nitrogen intake & 43.16 & 40.10 & 37.94 & 36.54 & 30.85 & 2.714 & 0.082 & 0.705 & 0.003 \\
\hline Retained/ingested & 0.45 & 0.47 & 0.44 & 0.37 & 0.17 & 0.082 & 0.538 & 0.754 & 0.036 \\
\hline Retained /absorbed & 0.57 & 0.59 & 0.57 & 0.48 & 0.19 & 0.110 & 0.580 & 0.784 & 0.032 \\
\hline \multicolumn{10}{|c|}{ Nitrogen ureic $\left(\mathrm{mg} \mathrm{Dl}^{-1}\right)$} \\
\hline SUN & 10.49 & 12.00 & 11.60 & 11.59 & 13.05 & 1.561 & 0.136 & 0.158 & 0.569 \\
\hline UUN & 54.42 & 61.56 & 59.54 & 56.64 & 67.73 & 4.632 & 0.964 & 0.311 & 0.209 \\
\hline $\mathrm{pH}$ & 6.02 & 6.16 & 6.04 & 6.08 & 6.15 & 1.76 & 0.842 & 0.464 & 0.155 \\
\hline $\mathrm{N}-\mathrm{NH} 3, \mathrm{mg} \mathrm{dL}^{-1}$ & 19.67 & 15.42 & 22.15 & 21.83 & 16.50 & 5.74 & 0.393 & 0.503 & 0.403 \\
\hline
\end{tabular}

${ }^{a}$ Contrasts Linear (L) and quadratic (Q); Roughage: Effect of the contrast between the treatment with $0 \%$ babassu cake with pineapple coproducts silage and the diet containing elephant grass silage as roughage. EGS: Elephant grass silage as roughage and corn and soybean meal-based concentrate; SEM: Standard error of the mean; SUN: Serum urea nitrogen; UUN: Urine urea nitrogen.

Another aspect that confirms the efficiency of protein digestion in the diets to which babassu cake was added is the absence of effects on the intake, retention, and absorption of nitrogen between the experimental diets. According to Hennessy and
Nolan (1988), in diets with nitrogen deficiency, most urea is recycled to provide an adequate supply of nitrogen in the rumen, and therefore, a reduction in its excretion via urine tends to occur. On the other hand, the excess nitrogen in ruminants causes an increase in the circulating 
ammonia levels and, later, an increase in the serum and urine levels of urea. However, in the present work, the urine urea nitrogen values were equal among the experimental diets, as were the serum urea nitrogen values, showing that no changes occurred in the recycling of urea with the addition of babassu cake to the diets. Thus, it is believed that the babassu cake, when partially replacing soybean meal, meet the nitrogen demands of sheep.

The sum of these factors suggests that the animals had sufficient nitrogen availability to meet their demands for microbial metabolism; thus, these animals may have similar performance to those fed soybean meal, because according to Detmann, Valente, Batista and Huhtanen (2014a), the nitrogen balance in the rumen reaches equilibrium at a minimum concentration of $9.2 \mathrm{mg}$ $\mathrm{N}-\mathrm{NH}_{3} \mathrm{dL}^{-1}$ of ruminal fluid. Considering the ammonia nitrogen levels in the present study (approximately $19 \mathrm{mg} \mathrm{dL}^{-1}$ ) (Table 5), animals probably had a good opportunity for nitrogen deposition because of the higher microbial growth and the transport of microbial protein to the abomasum. In addition, the ammonia nitrogen values were within the optimal range (10 to $20 \mathrm{mg} \mathrm{dL}^{-1}$ ) for ruminal degradation and DM intake, thus leading to maximum microbial growth (Leng, 1990). Moreover, the average $\mathrm{pH}$ values were also within the range (6.0-7.0) considered suitable for the growth of microorganisms, fermentation, and fiber degradation (Messana et al., 2013).

\section{Conclusion}

In sheep diets, soybean meal can be replaced by babassu cake at concentrations up to $80 \%$ when using PBS as roughage without compromising the intake of DM, NDF, CP, and
$\mathrm{NB}$, the levels of ammonia nitrogen or the $\mathrm{pH}$ of the ruminal fluid $\mathrm{pH}$, although it reduces the digestibility of nutrients. Furthermore, the replacement of EGS with PBS improved nutrient intake and NB in sheep.

\section{Conflict of interest}

We certify that there is no conflict of interest with any financial organization regarding the material discussed in the manuscript.

\section{Acknowledgments}

We thank the Brazilian National Council for Scientific and Technological Development (CNPq) for their financial support.

\section{References}

Allen, M. S. (1996). Physical constraints on voluntary intake of forages by ruminants. Journal Animal Science, 74(12), 30633075. doi: 10.2527/1996.74123063

Conceição, M. G., Ferreira, M. A. F., Campos, J. M. S., Silva, J. L., Detmann, E., Siqueira, M. C. B.,... Costa, C. T. F. (2016). Replacement of wheat bran with pineless cactus in sugarcane-based diets for steers. Revista Brasileira de Zootecnia, 45(4), 158-164. doi: 10.1590/S1806-92902016000400003

Decandia, M., Sitzia, M., Cabiddu, A., Kababya, D., \& Molle, G. (2000). The use of polyethylene glycol to reduce the antinutritional effects of tannins in goat fed woody species. Small Ruminant Research, 38(2), 157-164. doi: 10.1016/S0921-4488 (00)00145-0 
Detmann, E., \& Valadares, S. C., F . (2010). On the estimation of non-fibrous carbohydrates in feeds and diets. Arquivo Brasileiro de Medicina Veterinária e Zootecnia, 62(4), 980-984. doi: 10.1590/S0102-09 352010000400030

Detmann, E., Cecon, P. R., Paulino, M. F., Zervoudakis, J. T., Valadares, S. C., $F^{\circ}$., \& Araujo, C. V. (2001). Estimação de parâmetros da cinética de trânsito de partículas em bovinos sob pastejo por diferentes sequências amostrais. Revista Brasileira de Zootecnia, 30(1), 222230. doi: 10.1590/S1516-3598200100 0100031

Detmann, E., Gionbelli, M. P., \& Huhtanen, P. (2014b). A meta-analytical evaluation of the regulation of voluntary intake in cattle fed tropical forage-based diets. Journal Animal Science, 92(10), 4632-4641. doi: 10.2527/jas2014-7717

Detmann, E., Souza, M. A., \& Valadares, S. C., Fo. (2012). Métodos para análise de alimentos - INCT - Ciência Animal. Visconde do Rio Branco: Suprema.

Detmann, E., Valente, E. E. L., Batista, E. D., \& Huhtanen, P. (2014a). An evaluation of the performance and efficiency of nitrogen utilization in cattle fed tropical grass pastures with supplementation. Livestock Science, 162(1), 141-153. doi: 10.1016/j. livsci.2014.01.029

Gomes, D. I., Véras, R. M., Alves, K. S., Detmann, E., Oliveira, L. R. S., Mezzomo, R..., Barcelos, S. S. (2012). Performance and digestibility of growing sheep fed with açai seed meal-based diets. Tropical Animal Health Production, 44(7), 1751-1757. doi: 10.1007/s11250-012-0133-1
Hennessy, D. W., \& Nolan, J. V. (1988). Nitrogen kinetics in cattle fed a mature subtropical grass hay with and without protein meal supplementation. Australian Journal Agricultural Research, 39(6), 1135-1150. doi: 10.1071/AR9881135

Instituto Brasileiro de Geografia e Estatística (2013). Sistema de recuperação automática. Pesquisa pecuária municipal. Recuperado de http://www.sidra.ibge. gov.br

Izumi, K., Tamura, T., Fujii, R., Nakatsuji, H., \& Morita, S. (2018). Effects of substituting kraft pulp with corn silage on dry matter intake, ruminal mat formation, rumen fermentation, and rumination activity in non-lactating cows. Animal Science Journal, 90(2), 205-213. doi: 10.1111/asj. 13149

Kammers, K. L., \& Allen, M. S. (2011). Rates of particle size reduction and passage are faster for legume compared with coolseason grass, resulting in lower rumen fill and less effective fiber. Journal Dairy Science, 95(6), 3288-3297. doi: 10.3168/ jds.2011-5022

Lazzarini, I., Detmann, E.,, Paulino, M. F., Valadares, S. C., Fo., Valadares, R. F. D., Oliveira, F. A.,... Reis, W. L. S. (2013). Nutritional performance of cattle grazing on lowquality tropical forage supplemented with nitrogenous compounds and/or starch. Revista Brasileira de Zootecnia, 42(9), 664-674. doi: 10.1590/S1516-359 82013000900009

Leng, R. A. (1990). Factors affecting the utilization of "poor-quality" forages by ruminants particularly under tropical conditions. Nutrition Research Reviews, 3(9), 277-303. doi: 10.1079/NRR19900016 
Lins, S. E. B., Pessoa, R. A. S., Ferreira, M. A., Campos, J. M.S., Silva, J. A. B. A., Silva, J. L.,... Melo, T. T. B. (2016). Spineless cactus as a replacement for wheat bran in sugar canebased diets for sheep: intake, digestibility, and ruminal parameters. Revista Brasileira de Zootecnia, 45(1), 26-31. doi: 10. 1590/ S1806-92902016000100004

Messana, J. D., Berchielli, T. T., Arcuri, P. B., Reis, R. A., Canesin, R. C., Ribeiro, A. F.,... Fernandes, J. J. R. (2013). Rumen fermentation and rumen microbes in Nellore steers receiving diets with different lipid contentes. Revista Brasileira de Zootecnia, 42(3), 204-212. doi: 10.1590/ S1516-35982013000300008

National Research Council (2000). Nutrient requirements of beef cattle (7nd ed.). Washington, DC: National Academy Press.

National Research Council (2007). Nutrient requirements of sheep (6nd rev.). Washington, DC: National Academy Press.

Ranathunga, S. D., Kalscheur, K. F., \& Herrick, K. J. (2019). Ruminal fermentation, kinetics, and total-tract digestibility of lactating dairy cows fed distillers dried grains with solubles in low and high-forage diets. Journal of Dairy Science, 102(9), 79807996. doi: 10.3168/jds.2018-15771

Sá, H. C. M., Borges, I., Macedo, G. L., Jr., Neiva, J. N. M., Sousa, J. T. L., \& Paula, S. M. (2015). Consumo e comportamento ingestivo de ovinos mestiços alimentados com torta do babaçu (Orbignya spp.). Journal Bioscience, 31(1), 107-113. doi: 10.14393/ BJ-v31n1a2015-18221
Santos, E. R., Neta, Alves, K. S., Mezzomo, R., Gomes, D. I., Oliveira, L. R. S., Carvalho, F. F. R.,... Bourdon, V. D. S. (2017). Behavior of sheep fed babassu cake (Orbygnia speciosa) as a substitution for elephant grass silage. Animal Science Journal, 88(8), 1171-1177. doi: 10.1111/asj.12744

Statistical Analysis Software [SAS] (2012). Statistical data bases. Retrieved from http://faostat.fao.org

United Nations Conference on Trade and Development (2016). Pineapple: An INFOCOMM Commodity Profile. Retrieved from http://unctad.org/en/ PublicationsLibrary/INFOCOMM_cp09_ Pineapple_en.pdf

Valente, T. N. P., Detmann, E., Valadares, S. C., $F^{\circ}$., Cunha, M., Queiroz, A. C., \& Sampaio, C. B. (2011). In situ estimation of indigestible compounds contents in cattle feed and feces using bags made from different textiles. Revista Brasileira de Zootecnia, 40(3), 666-675. doi: 10.1590/S151635982011000300027

Van Soest, P. J. (1965). Symposium on factors influencing the voluntary intake of herbage by ruminants: voluntary intake relation to chemical composition on and digestibility. Journal Animal Science, 24(3), 834-844. doi: $10.2527 /$ jas 1965.243834x 
